\title{
Observations on the haemopoietic response to critical illness
}

\author{
R J Amos, M Deane, C Ferguson, G Jeffries, C J Hinds, J A L Amess
}

\begin{abstract}
Peripheral blood cytopenias are common in patients receiving intensive care, particularly in those with multiple organ failure. To assess the contribution of bone marrow hypoplasia in such patients 44 bone marrow samples from 24 patients under intensive care were studied by standard morphological techniques and by the granulocyte-macrophage colony forming cell (GM-CFC) assay. Frequently observed morphological abnormalities in the bone marrow included the following: (i) a reduction in overall cellularity in seven patients, with a progressive decrease in most patients studied sequentially; (ii) an increase in the number of actively phagocytic macrophages; and (iii) a disruption of normal bone marrow architecture with the accumulation of intercellular hyaluronic acid glycosaminoglycan. Mean GM-CFC growth was significantly reduced when compared with that in a group of normal controls. In four of five patients studied sequentially GM-CFC growth became subnormal in association with a reduction in bone marrow cellularity. Inhibitory serum factors were not identified. These morphological abnormalities are similar to the changes observed in gelatinous degeneration of the bone marrow.

In both situations disruption of the haemopoietic microenvironment, with the accumulation of hyaluronic acid proteoglycan, may be an important factor in the inhibition of haemopoietic progenitor cell growth. The proliferation of macrophages, by the release of a variety of cytokines or reactive oxygen intermediates, may also be implicated in impaired haemopoiesis and the development of disordered erythropoiesis.
\end{abstract}

Department of Haematology, St Bartholomew's Hospital,

West Smithfield, London EC1

R J Amos

$M$ Deane

$\mathrm{J}$ A L Amess

Intensive Care Unit

C Ferguson

G Jeffies

C J Hinds

Correspondence to:

Dr R J Amos.

Accepted for publication

11 June 1990

Persistent or recurrent sepsis, often associated with multiple organ failure, is a common clinical finding in patients receiving intensive care. ${ }^{1}$ The haematological response in this situation often seems to be inadequate; anaemia is almost universal and variable degrees of thrombocytopenia are common. The neutrophil count may be inappropriately low and overt neutropenia may supervene. It is clearly very difficult in such complex situations to define causative factors; several elements may be involved in the development of anaemia, including blood loss, the "anaemia of chronic disorder," 33 and haemolysis. ${ }^{4}$ The presence of thrombocytopenia and neutropenia is often explained on the basis of an increase in the peripheral consumption of mature cells due, for example, to infection or disseminated intravascular coagulation. From previous observations, however, it is our impression that bone marrow hypoplasia and the subsequent failure of blood cell production is an important additional factor in the development of these cytopenias.

Of particular interest is the possible association between multiple organ failure and impaired haemopoiesis. The syndrome of sequential/progressive multiple organ failure came to prominence in the 1970 s when it became possible to resuscitate and support patients with previously lethal critical illness..$^{5-8}$ No generally agreed definition of this clinical syndrome is available but it is characterised by a hypermetabolic state, usually in association with infection, together with failure of the lungs, kidneys, heart and circulation, liver and gastrointestinal tract. ${ }^{8}$ Considerable interest has recently been focused on a group of peptide mediators derived from activated monocytes and lymphocytes, such as interleukin 1 (IL-1), interleukin 2 (IL-2), and tumour necrosis factor (TNF), which may be implicated in the pathogenesis of multiple organ failure..$^{8-10}$ It has been suggested that continued, uncontrolled production of these mediators of acute inflammation, in response, for example, to overwhelming infection or tissue necrosis, may be one of the mechanisms underlying damage to vital organs. ${ }^{8}$ These peptides also have a wide range of effects on the haemopoietic system, including the mediation of acute changes in iron metabolism, ${ }^{2}$ direct effects on haemopoietic progenitor cell proliferation, ${ }^{11-13}$ regulation of haemopoietic colony stimulating factor gene expression, ${ }^{14-17}$ and modulation of the response of haemopoietic progenitor cells to colony stimulating factors. ${ }^{18}$

\section{Methods}

Observations were made on 24 patients (18 men and six women, mean age 52 years, range 18-78 years) admitted to the intensive care unit (ICU) at this hospital. Seventeen died, giving a mortality of $64 \%$. Brief clinical details are provided in table 1 . Patients with primary haematological disorders and those 
Table 1 Brief clinical details and peripheral blood data of 24 patients studied

\begin{tabular}{|c|c|c|c|c|c|c|}
\hline \multirow[b]{2}{*}{ Case No } & \multirow[b]{2}{*}{ Clinical details } & \multirow[b]{2}{*}{$\begin{array}{l}\text { Exposure to } \\
\text { nitrous oxide }\end{array}$} & \multirow[b]{2}{*}{ Outcome } & \multicolumn{3}{|c|}{ Mean (range) peripheral blood findings } \\
\hline & & & & $\begin{array}{l}\text { Haemoglobin } \\
(\mathrm{g} / \mathrm{dl})\end{array}$ & $\begin{array}{l}\text { Neutrophils } \\
\left(\times 10^{9} \mid l\right)\end{array}$ & $\begin{array}{l}\text { Platelets } \\
\left(\times 10^{9} \mid l\right)\end{array}$ \\
\hline $\begin{array}{rl}1 & M / 58 \\
2 & M / 71 \\
3 & F / 70 \\
4 & M / 19 \\
5 & F / 22 \\
6 & M / 32 \\
7 & M / 56 \\
8 & M / 29 \\
9 & M / 50 \\
10 & M / 23 \\
11 & M / 68 \\
12 & M / 34 \\
13 & M / 70 \\
14 & F / 39 \\
15 & F / 67 \\
16 & M / 62 \\
17 & M / 73 \\
18 & M / 61 \\
19 & F / 52 \\
20 & F / 77 \\
21 & M / 63 \\
22 & M / 60 \\
23 & M / 31 \\
24 & M / 74\end{array}$ & $\begin{array}{l}\text { Cardiac arrest } \\
\text { Aortic aneurysm repair } \\
\text { CAVBG/AVR } \\
\text { Multiple injuries } \\
\text { Head injury/IC surgery } \\
\text { Septicaemia/debridement } \\
\text { CAVBG } \\
\text { Proctocolectomy } \\
\text { Head injury/subdural } \\
\text { Stab wound } \\
\text { Subdural haematoma } \\
\text { Pancreatitis } \\
\text { Aortic aneurysm } \\
\text { Abdominal sepsis } \\
\text { Laparotomy/septicaemia } \\
\text { Septicaemia/tracheostomy } \\
\text { Aortic aneurysm } \\
\text { Aortic aneurysm } \\
\text { Septicaemia } \\
\text { MVR/AVR } \\
\text { Laparotomy/pneumonia } \\
\text { Pancreatitis } \\
\text { Cardiac arrest } \\
\text { Bowel perforation }\end{array}$ & $\begin{array}{l}\text { No } \\
\text { Yes } \\
\text { Yes } \\
\text { Yes } \\
\text { Yes } \\
\text { Yes } \\
\text { Yes } \\
\text { Yes } \\
\text { Yes } \\
\text { Yes } \\
\text { Yes } \\
\text { No } \\
\text { Yes } \\
\text { No } \\
\text { Yes } \\
\text { Yes } \\
\text { Yes } \\
\text { Yes } \\
\text { No } \\
\text { Yes } \\
\text { Yes } \\
\text { No } \\
\text { No } \\
\text { Yes }\end{array}$ & $\begin{array}{l}\text { D } \\
\text { D } \\
\text { D } \\
\text { A } \\
\text { A } \\
\text { A } \\
\text { D } \\
\text { A } \\
\text { A } \\
\text { A } \\
\text { D } \\
\text { D } \\
\text { D } \\
\text { A } \\
\text { D } \\
\text { D } \\
\text { D } \\
\text { D } \\
\text { D } \\
\text { D } \\
\text { D } \\
\text { D } \\
\text { D } \\
\text { D }\end{array}$ & $\begin{array}{l}14 \cdot 6(13 \cdot 4-16 \cdot 2) \\
9 \cdot 6(8 \cdot 6-10 \cdot 9) \\
10 \cdot 7(6 \cdot 5-113 \cdot 2) \\
12 \cdot 1(10 \cdot 5-13 \cdot 9) \\
10 \cdot 1(6 \cdot 8-12 \cdot 3) \\
10 \cdot 5(8 \cdot 3-11 \cdot 4) \\
12 \cdot 1(10 \cdot 0-18 \cdot 0) \\
11 \cdot 3(9 \cdot 0-16 \cdot 6) \\
10 \cdot 6(9 \cdot 4-11 \cdot 2) \\
10 \cdot 5(8 \cdot 3-12 \cdot 6) \\
10 \cdot 7(8 \cdot 5-15 \cdot 6) \\
12 \cdot 1(8 \cdot 3-15 \cdot 2) \\
11 \cdot 3(9 \cdot 7-12 \cdot 5) \\
10 \cdot 0(9 \cdot 8-10 \cdot 2) \\
9 \cdot 9(7 \cdot 7-11 \cdot 7) \\
9 \cdot 2(7 \cdot 0-14 \cdot 9) \\
10 \cdot 2(9 \cdot 6-10 \cdot 8) \\
11 \cdot 6(8 \cdot 4-16 \cdot 0) \\
11 \cdot 6(7 \cdot 8-14 \cdot 5) \\
9 \cdot 7(7 \cdot 8-12 \cdot 4) \\
10 \cdot 2(7 \cdot 4-11 \cdot 6) \\
10 \cdot 2(9 \cdot 5-11 \cdot 7) \\
10 \cdot 2(7 \cdot 6-13 \cdot 4) \\
11 \cdot 3(8 \cdot 8-13 \cdot 0)\end{array}$ & $\begin{array}{c}14 \cdot 0(9 \cdot 3-16 \cdot 0) \\
14 \cdot 3(5 \cdot 2-19 \cdot 7) \\
11 \cdot 6(3 \cdot 1-29 \cdot 0) \\
13 \cdot 0(5 \cdot 5-25 \cdot 7) \\
11 \cdot 2(8 \cdot 6-15 \cdot 7) \\
10 \cdot 9(5 \cdot 6-11 \cdot 4) \\
14 \cdot 6(7 \cdot 6-28 \cdot 3) \\
11 \cdot 7(5 \cdot 9-45 \cdot 5) \\
8 \cdot 0(5 \cdot 6-11 \cdot 6) \\
14 \cdot 3(8 \cdot 0-22 \cdot 0) \\
6 \cdot 7(6 \cdot 3-9 \cdot 6) \\
14 \cdot 6(3 \cdot 4-26 \cdot 2) \\
11 \cdot 7(5 \cdot 1-14 \cdot 4) \\
15 \cdot 0(13 \cdot 5-16 \cdot 5) \\
6 \cdot 4(2 \cdot 0-12 \cdot 0) \\
8 \cdot 2(5 \cdot 2-12 \cdot 2) \\
12 \cdot 4(8 \cdot 5-15 \cdot 2) \\
15 \cdot 8(3 \cdot 0-30 \cdot 0) \\
11 \cdot 4(2 \cdot 9-34 \cdot 0) \\
17 \cdot 6(10 \cdot 0-28 \cdot 8) \\
11 \cdot 1(5 \cdot 4-21 \cdot 6) \\
15 \cdot 6(10 \cdot 6-18 \cdot 5) \\
13 \cdot 0(8 \cdot 1-26 \cdot 7) \\
8 \cdot 5(3 \cdot 0-11 \cdot 6)\end{array}$ & $\begin{array}{c}169(121-296) \\
250(130-444) \\
57(16-128) \\
181(103-380) \\
244(107-446) \\
242(17-467) \\
66(11-210) \\
393(239-529) \\
266(108-544) \\
337(106-545) \\
174(124-249) \\
111(47-242) \\
46(16-95) \\
556(498-614) \\
142(67-247) \\
156(57-167) \\
105(72-261) \\
79(16-168) \\
121(16-221) \\
133(21-228) \\
141(57-306) \\
127(54-266) \\
451(221-610) \\
88(15-273)\end{array}$ \\
\hline
\end{tabular}

D-Died on the ICU.

A-Discharged alive from the ICU.

CAVBG - Coronary artery vein bypass graft.

AVR-Aortic valve replacement.

MVR-Mitral valve replacement.

Table 2 Bone marrow findings in 24 patients studied

\begin{tabular}{|c|c|c|c|c|c|c|c|}
\hline Case No & Cellularity & Erythropoic & iesis & Macrophages & $\begin{array}{l}\text { Intercellular } \\
\text { material }\end{array}$ & Fat atrophy & $\begin{array}{l}G M-C F C / \\
10^{s} \text { cells }\end{array}$ \\
\hline $\begin{array}{l}1.1 \\
1.2\end{array}$ & $\begin{array}{l}\text { NC } \\
\text { NC }\end{array}$ & $\begin{array}{l}\mathrm{NCMB} \\
\mathrm{NC} \mathrm{MB}\end{array}$ & + & $\begin{array}{l}+ \\
+\end{array}$ & & & - \\
\hline 1.3 & NC & $\mathrm{NC} \mathrm{MB}$ & & ++ & + & & $\overline{146}$ \\
\hline 1.4 & NC & $\mathrm{NCMB}$ & + & ++ & ++ & & 30 \\
\hline 1.5 & NC & NC MB & & ++ & ++ & ++ & 48 \\
\hline 2.1 & NC & RED MB & + & + & + & 1 & - \\
\hline 2.2 & & NC & & ++ & ++ & + & - \\
\hline 2.3 & NC/RED & NC & + & ++ & $t+$ & & - \\
\hline 2.4 & RED & NC & + & ++ & $\begin{array}{l}++ \\
+\end{array}$ & + & -70 \\
\hline 3.1 & NC/RED & NC & + & $\begin{array}{l}+ \\
++\end{array}$ & & & 70 \\
\hline $\begin{array}{l}3.2 \\
4.1\end{array}$ & $\begin{array}{l}\text { NC/RED } \\
\text { NC }\end{array}$ & $\begin{array}{l}\text { NC } \\
\text { NC MB }\end{array}$ & + & $\begin{array}{l}++. \\
+\end{array}$ & & & 41 \\
\hline 4.2 & RED & RED & & ++ & + & + & 120 \\
\hline 5.1 & RED & RED MB & & + & + & + & - \\
\hline 5.2 & RED & RED & & + & ++ & + & - \\
\hline 6.1 & NC & NC MB & & + & + & + & - \\
\hline 6.2 & NC/RED & NC MB & & + & ++ & ++ & - \\
\hline 6.3 & NC/RED & NC MB & & ++ & ++ & $+t$ & 86 \\
\hline 7.1 & NC/RED & RED & + & ++ & + & $T$ & - \\
\hline 7.2 & RED & RED & + & +++ & + & + & - \\
\hline 8 & NC & NC & + & + & & & 4 \\
\hline 9.1 & NC & NC MB & & + & + & & - \\
\hline $\begin{array}{r}9.2 \\
10.1\end{array}$ & NC & $\mathrm{NC} \mathrm{MB}$ & + & ++ & ++ & & 97 \\
\hline $\begin{array}{l}10.1 \\
10.2\end{array}$ & NC & NC & + & + & + & & - \\
\hline $\begin{array}{l}10.2 \\
10.3\end{array}$ & NC & NC & & ++ & + & & - \\
\hline $\begin{array}{l}10.3 \\
11.1\end{array}$ & $\begin{array}{l}\text { NC } \\
\text { RFD }\end{array}$ & NC & & +++ & + & ++ & - \\
\hline $\begin{array}{l}11.1 \\
11.2\end{array}$ & RED & NC MB & + & +++ & + & & 83 \\
\hline 11.2 & RED & RED & + & ++++ & + & & 26 \\
\hline 12 & NC & RED & & + & . & & - \\
\hline 13 & RED & NC MB & ++ & +++ & + & & 25 \\
\hline 14 & NC & RED & & & & & 66 \\
\hline 15 & NC & RED & + & & & & 30 \\
\hline 16 & NC & RED MB & & +++ & & & 74 \\
\hline 17 & NC & RED & + & ++ & & & 35 \\
\hline 18 & $\mathrm{NC}$ & RED & ++ & & & & 34 \\
\hline 19 & NC & RED & ++ & & & & 18 \\
\hline 20 & $\begin{array}{l}\text { RED } \\
\text { NC }\end{array}$ & $\begin{array}{l}\text { RED } \\
\text { RED }\end{array}$ & & + & & & 41 \\
\hline 21.2 & NC & $\begin{array}{l}\text { RED } \\
\text { NC }\end{array}$ & & ++ & & & - \\
\hline 22 & NC & $\mathrm{NC}$ & + & +++ & & & - \\
\hline 23.1 & NC & RED & + & ++ & + & & - \\
\hline 23.2 & NC & RED & + & ++ & + & & 90 \\
\hline 24.1 & $\mathrm{NC}$ & RED & + & ++ & & & 223 \\
\hline 24.2 & NC & RED MB & ++ & +++ & + & & 22 \\
\hline
\end{tabular}

Trephine biopies were performed in patients 1-11. In patients studied on more than one occasion the bone marrows are numbered consecutively. Semiquantitative estimates (indicated by + ) are provided for dyserythropoiesis (under erythropoiesis), macrophage numbers, intercellular material and fat atrophy.

NC-Normocellular.

RED-Reduced cellularity.

NC/RED-Areas of both normal and reduced cellularity.

MB-Megaloblastic. 
Figure 1 Bone marrow trephine biopsy specimen (case 7.2) showing early morphological changes with areas of focal hypoplasia, loss of haemopoietic cells, and the accumulation of intercellular material (haematoxylin and eosin).

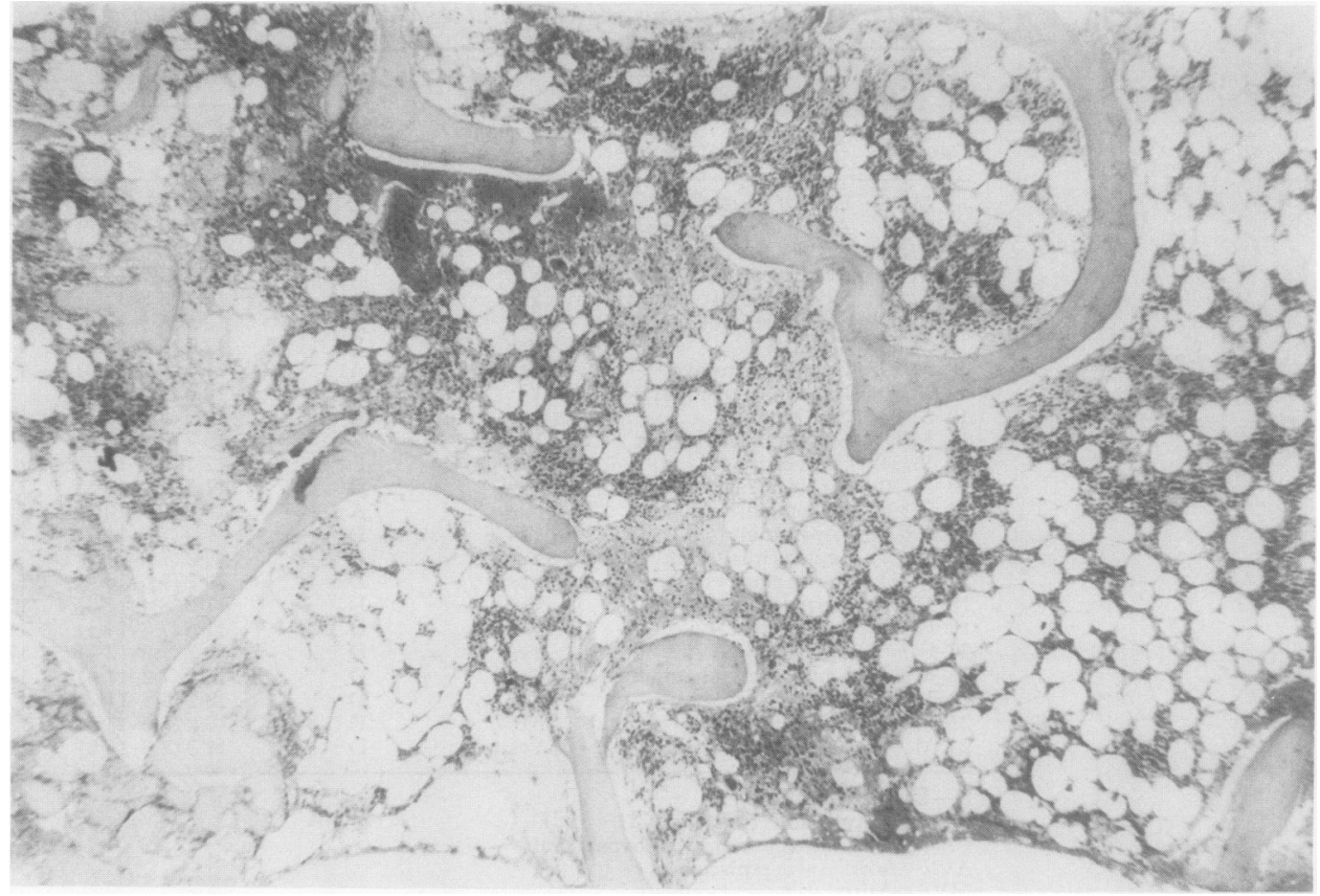

who had received cytotoxic chemotherapy or radiotherapy were excluded. Eighteen patients were admitted within 24 hours of surgery and anaesthesia with nitrous oxide. None of the patients was exposed to nitrous oxide after admission to the Unit during the period of study. All patients received parenteral folate supplementation during admission $(1 \mathrm{mg} /$ day). They remained in the ICU for a mean of 20 days (range seven to 49 days).

The study was approved by the local ethical committee. Whenever possible, informed consent for participation in the study was obtained from the patients; otherwise it was obtained from their next of kin.

\section{BONE MARROW MORPHOLOGY}

Forty four bone marrow samples were obtained from the 24 patients in the study; 28 samples from 11 patients included a bone marrow trephine biopsy specimen. Eleven patients were studied on only one occasion, on average nine days after admission (range one to 30 days); 13 patients were studied sequentially, on two or more occasions, every three days for periods of up to 14 days.

All samples were processed using standard techniques. Aspirate smears were fixed in methanol and stained by May-Grun̈waldGiemsa and Perls's reaction for iron. Trephine biopsy specimens were decalcified,
Figure 2 Central area of fig 1, enlarged, showing disruption and loss of normal fat spaces.

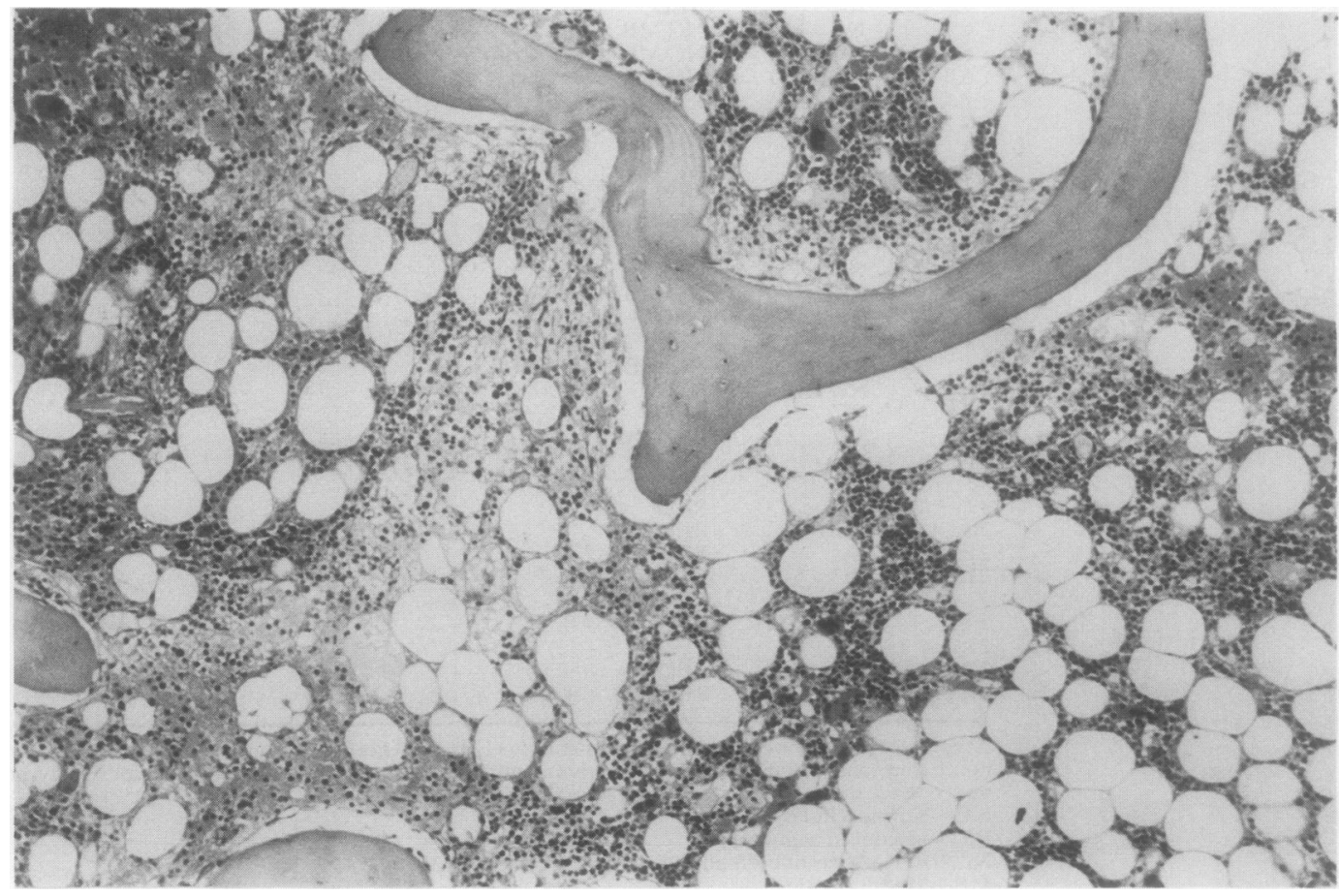


Figure 3 Bone marrow trephine biopsy specimen (case 2.4) showing an extensive area of marrow hypoplasia. Hyaluronic acid glycosaminoglycan is present in the spaces between the fat cells (haematoxylin and eosin).

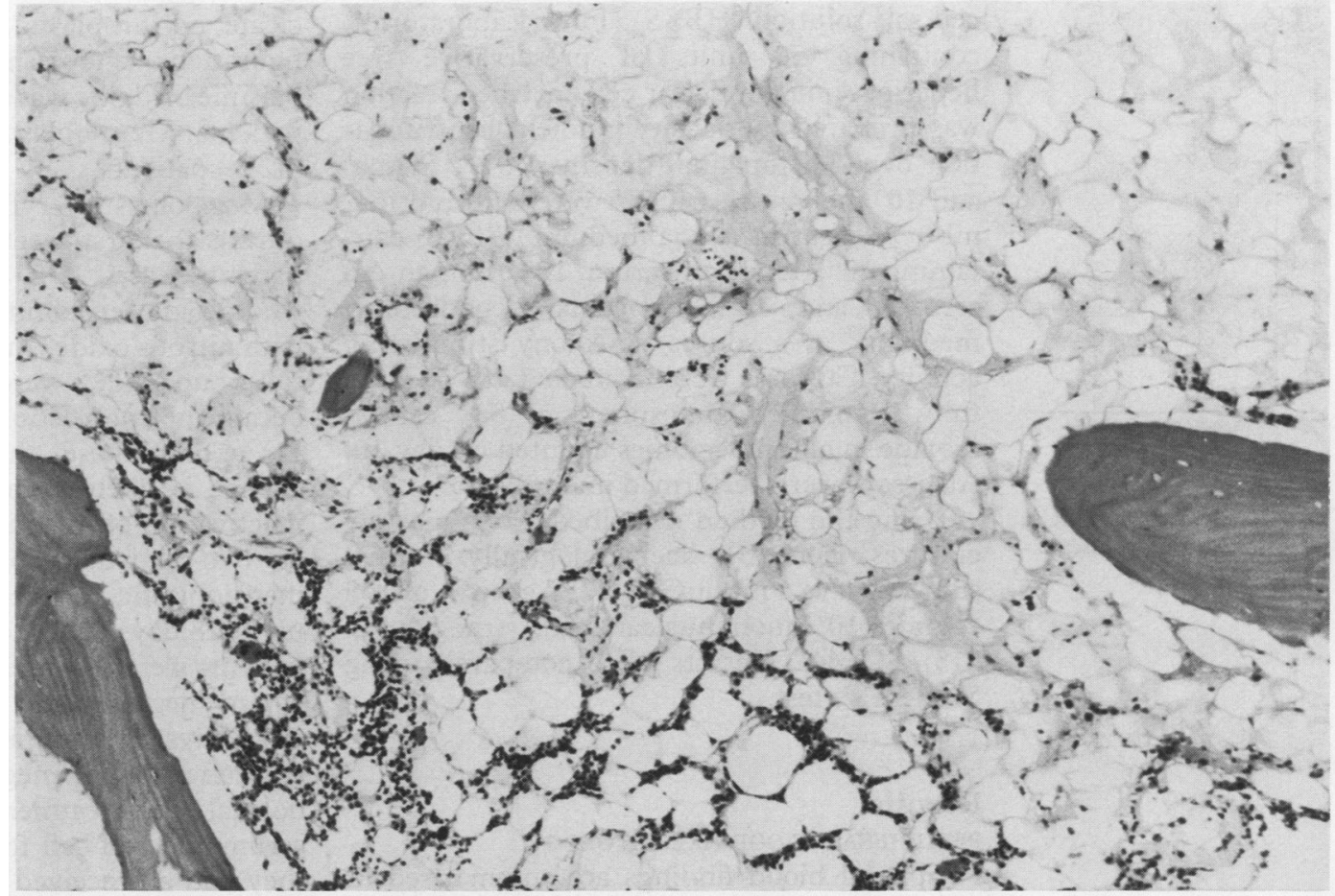

paraffin wax embedded, sectioned and stained with haematoxylin and eosin and by silver impregnation for reticulin. Selected trephine biopsy specimens were studied by additional histochemical techniques including periodic acid Schiff (PAS) (neutral polysaccharides), PAS with diastase (glycogen), alcian blue at pH $2.5+1-$ hyaluronidase (hyaluronic acid) and alcian blue at $\mathrm{pH} 1.0$ (sulphated mucopolysaccharides). Bone marrow slides were reviewed independently by three observers (RJA, JALA, and MD) and the findings collated.

A blood count, including examination of a peripheral blood film, was performed on a daily basis. Serum vitamin $B_{12}$ and serum and red cell folate were estimated by microbiological assay before starting treatment with prophylactic folic acid. Other investigations were performed as clinically indicated.

\section{BONE MARROW CULTURE STUDIES}

Bone marrow culture studies were performed on 17 patients; in 12 patients on one occasion and in five patients sequentially. the granulocyte-macrophage colony forming cell assay (GM-CFC) ${ }^{19}$ Briefly, bone marrow cells were collected into $10 \mathrm{ml}$ Hanks's balan-
Myeloid progenitor cells were assayed in
Figure 4 Bone marrow aspirate (case 11.2) showing increased numbers of macrophages with foamy cytoplasm; some contain necrotic cellular debris (May-Grünwald Giemsa).

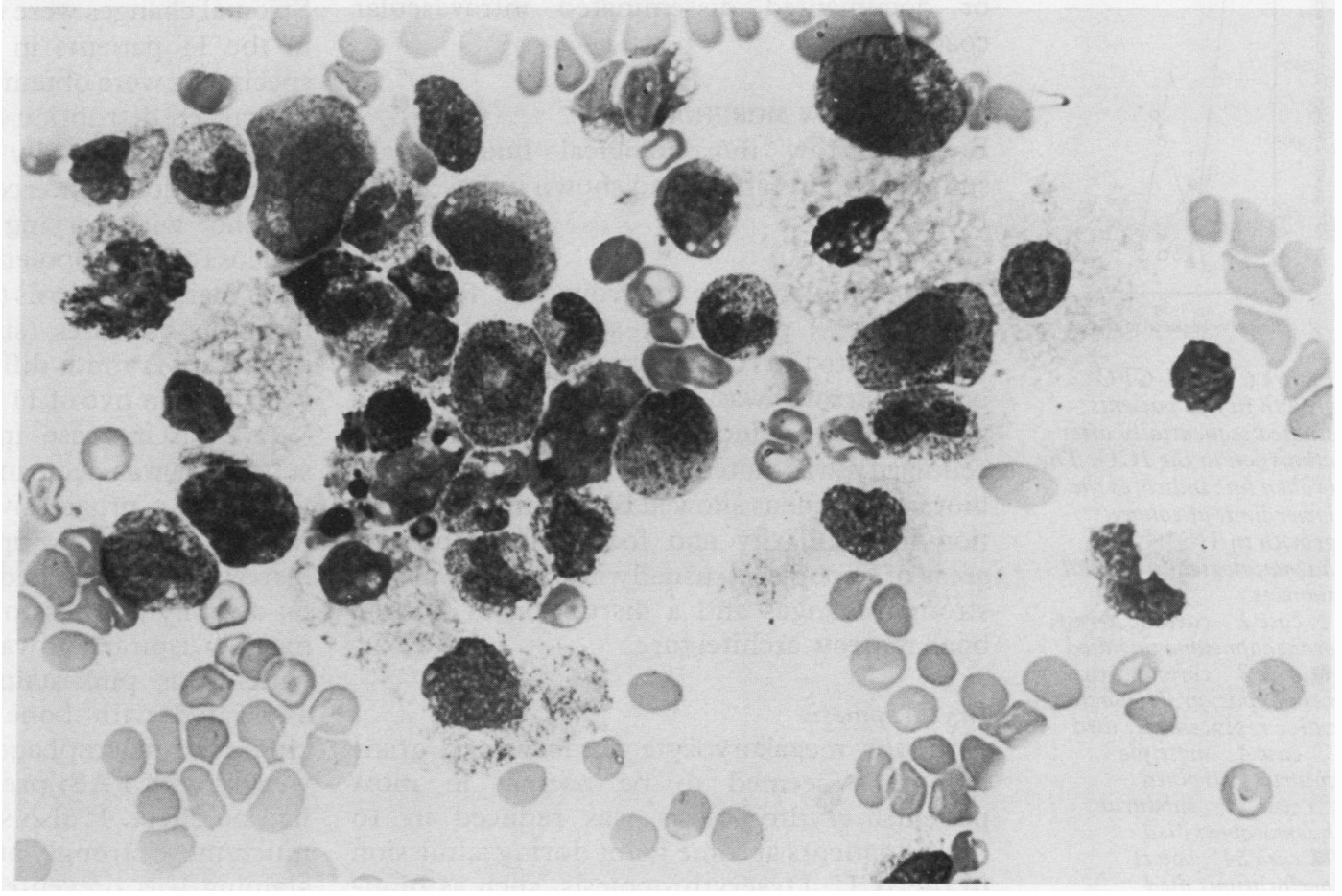




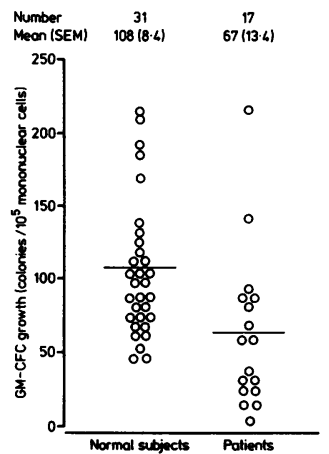

Figure 5 GM-CFC growth in 31

haematologically normal subjects and in 17 patients from the ICU. ced salt solution (HBSS) (Flow Laboratories) containing 50 units of preservative free heparin. A mononuclear cell enriched fraction was prepared by density gradient centrifugation over Histopaque (density 1.077; Sigma) and $10^{5}$ mononuclear cells were cultured in 2 $\mathrm{ml} \mathrm{0.3 \%}$ agar in Alpha medium (Gibco) containing $10 \%$ fetal calf serum, $10 \%$ human $A B$ serum, and $5 \%$ placental conditioned medium $^{20}$ as a source of colony stimulating activity. Cultures were incubated at $37^{\circ} \mathrm{C}$ in a fully humidified atmosphere of $5 \%$ carbon dioxide in air and colonies counted on day 10 . All assays were performed in duplicate.

Using the method described, bone marrow cultures from 31 haematologically normal subjects gave a mean GM-CFC growth of 108 colonies $/ 10^{5}$ mononuclear cells (range 40 215; SD 44). Results were compared using Student's $t$ test.

\section{Results}

PERIPHERAL BLOOD HAEMATOLOGY

Peripheral blood findings are summarised in table 1. Anaemia was almost universal. A number of red cell abnormalities were commonly observed, including rouleaux formation, target cells, burr cells and irregularly contracted cells, together with occasional red cell fragments and spherocytes. When tested, the direct antiglobulin test was uniformly negative.

Overt neutropenia (neutrophils $<2.5 \times$ $10^{9} / 1$ ) only developed in one patient, but in six patients the neutrophil count was $<3.5 \times$ $10^{9} / 1$ in the context of severe infection. Characteristically, peripheral blood neutrophils showed toxic granulation and cytoplasmic vacuolation. Immature granulocytes were often present.

Thrombocytopenia (platelets $<140 \times 10^{9} / 1$ ) developed in $21(83 \%)$ patients usually in association with massive blood transfusion or documented disseminated intravascular coagulation.

\section{BONE MARROW MORPHOLOGY}

Bone marrow morphological findings are summarised in table 2 and shown in figs 1-4.

\section{Cellularity}

A hypocellular bone marrow was found in seven $(29 \%)$ patients at some point during admission to the ICU. Of the 13 patients whose bone marrow was studied sequentially, a progressive reduction in bone marrow cellularity was noted in $10(77 \%)$. Trephine biopsy specimens showed both a diffuse reduction in cellularity and focal, intertrabecular areas of hypoplasia, usually in association with stromal changes and a disruption of normal bone marrow architecture.

\section{Erythropoiesis}

Although megakaryocyte numbers and granulopoiesis seemed to be normal in most patients, erythropoiesis was reduced in 16 $(66 \%)$ patients at some point during admission to the ICU. Dyserythropoiesis, such as binu- cleate erythroblasts, abnormal nuclear configurations, cytoplasmic vacuolation and cytoplasmic bridging was also observed in $17(71 \%)$ patients. Megaloblastic change was noted in 10 $(42 \%)$ patients.

Megaloblastic erythropoiesis was observed during the first week of admission in seven patients (cases 1, 2, 4-6, 11, and 13), six of whom had been admitted following anaesthesia with nitrous oxide. In the six patients in whom follow up studies were available erythropoiesis became normoblastic in four (cases $2,4,5$, and 11) and in these, the original megaloblastic change is likely to have been related to the inactivation of vitamin $B_{12}$ by nitrous oxide. ${ }^{21}$ In two patients, however (cases 1 and 6), megaloblastic change persisted for periods of up to 18 days and, in addition, a further three patients were identified (cases 9,16 , and 24) in whom megaloblastic change developed seven to 20 days after admission. These five patients with unexplained megaloblastic change all had normal pre-treatment serum vitamin $\mathbf{B}_{12}$, serum and red cell folate concentrations, and they had all received prophylactic folate supplements.

\section{Abnormal cells}

A moderate increase in the number of mature plasma cells (up to $10 \%$ ) was noted in $13(54 \%$ ) patients. An almost universal observation in 22 $(92 \%)$ patients was a variable and sometimes striking increase in the number of foamy, actively phagocytic macrophages. Many of the macrophages contained phagocytosed red cells, granulocytes or platelets. They occurred singly or in clumps and in the latter case were sometimes associated with fibrillary, pinkstaining material. There was a progressive increase in the number of macrophages in 11 of the $13\left(85^{\circ}\right)$ patients studied sequentially.

\section{Stromal changes}

Stromal changes were most clearly appreciated in the 11 patients in whom trephine biopsy specimens were obtained. Typically, there was a localised disruption of normal bone marrow architecture, usually associated with the accumulation of intercellular ground substance together with varying degrees of fat atrophy and loss of haemopoietic cells. In some patients bone marrow necrosis (one out of 11) and focal, fibrinous exudates (six out of 11) were also identified. A mild, diffuse increase in reticulin was noted in five of 11 patients.

A focal increase in pink-staining ground substance was seen in 10 of 11 patients and there was a progressive increase in the seven patients with follow up trephine biopsies. The material was associated with varying degrees of fat atrophy and loss of haemopoietic cells. In marrow aspirates it was identified in $13(54 \%)$ patients as pink-staining, fibrillary material associated with bone marrow fragments or clumps of macrophages. The material stained weakly with PAS; pre-digestion with diastase had no effect. It also stained with alcian blue, much more strongly at $\mathrm{pH} 2.5$ than at $\mathrm{pH} 1.0$; staining was prevented by pretreatment with 
hyaluronidase. Negative results were obtained with Congo red and silver impregnation. The histochemical reactions suggest that the extracellular material consists of acidic mucopolysaccharides, predominantly hyaluronic acid-that is, hyaluronic acid glycosaminoglycan, one of the proteoglycans widely distributed in the extra-cellular environment. ${ }^{22}$

\section{BONE MARROW CULTURE}

Bone marrow was cultured from 17 patients. The mean GM-CFC growth was 67 colonies/ $10^{5}$ mononuclear cells (range 4-222). This compares with results from a group of normal subjects where mean GM-CFC growth was 108 colonies $/ 10^{5}$ mononuclear cells (range 40 215) (fig 5). The difference between the two groups was significant $(p<0.01)$. In $\operatorname{six}(38 \%)$ patients colony growth was less than the range found in normal subjects.

In five patients GM-CFC assays were performed on more than one occasion. In four of five patients GM-CFC growth decreased and became subnormal during admission to the ICU; in each case this was associated morphologically with a reduction in bone marrow cellularity (fig 6). All four patients died.

The addition of autologous serum to cultures of patients' bone marrow produced no inhibition of colony growth, and similarly, the addition of patients' serum to cultures of bone marrow from normal subjects did not inhibit colony growth. There was therefore no evidence of any serum factors inhibitory to haemopoietic progenitor cell growth.

\section{Discussion}

We have described a constellation of morphological abnormalities in the bone marrow of a group of patients with critical illness. In essence they consist of: (1) hypoplasia, which was also reflected by a reduction in haemopoietic progenitor cell growth in vitro; (2) disruption of normal bone marrow architecture, with the accumulation of abnormal intercellular material, identified as hyaluronic acid glycosaminoglycan, variable degrees of fat atrophy, fibrinous exudates and bone marrow necrosis; and (3) proliferation of actively phagocytic macrophages. A reduction in erythropoiesis was also almost universal and was often associated with dyserythropoietic and megaloblastic change, the latter apparently unrelated to vitamin $B_{12}$ or folate deficiency. In a proportion of patients, particularly in those who developed multiple organ failure and who subsequently died, these changes seemed to have been progressive.

There was no clear association between the presence or severity of these changes and peripheral blood variables, an observation which is perhaps not surprising in view of the complex, interacting factors that determine the peripheral blood count in such patients. These morphological abnormalities, however, do probably limit the capacity of the bone marrow to respond appropriately: Indeed, we have direct evidence in vitro of impaired haemopoietic progenitor cell proliferation.
There are some similarities between the abnormalities we have noted and the changes seen in gelatinous degeneration of the bone marrow. ${ }^{2324}$ In this condition bone marrow hypoplasia, fat atrophy, and the accumulation of acidic mucopolysaccharide ground substance, identified as predominantly hyaluronic acid, ${ }^{24} 25$ develop in patients chronically malnourished for prolonged periods of time. It has been observed in tuberculosis and other long standing infections, ${ }^{23}$ disseminated malignancy, ${ }^{2324}$ anorexia nervosa ${ }^{25-30}$ and in one patient maintained on chronic intravenous nutrition. ${ }^{31}$ In the latter two situations gelatinous degeneration has been associated with peripheral blood cytopenias or pancytopenia. Interestingly, in some patients refeeding and clinical improvement have been associated with resolution of the bone marrow abnormalities or the peripheral blood cytopenias. ${ }^{27} 30$ It has been emphasised that gelatinous degeneration is a feature of conditions characterised by energy or carbohydrate deprivation and is not a feature of protein malnutrition. ${ }^{26}$ These considerations may have some relevance to the abnormalities noted in patients receiving intensive care, but a striking dissimilarity is the rapidity with which the changes we have described develop and progress.

Whatever the precise association is between the abnormalities in ICU patients and in gelatinous degeneration it is clear that in both situations major disruption of the haemopoietic microenvironment occurs. This is reflected particularly by changes in the extra-cellular matrix, which may be directly implicated in the development of impaired haemopoiesis. There is now considerable evidence that the bone marrow microenvironment has an important role in haemopoietic cell regulation and differentiation. ${ }^{3233}$ Of particular importance are the proteoglycans of the extra-cellular matrix ${ }^{34} 35$ which may regulate haemopoietic activity by influencing the diffusion of large macromolecules, including haemopoietic growth factors, ${ }^{22}$ by direct binding of haemopoietic growth factors ${ }^{36}{ }^{37}$ and by effects on cell adhesion and detachment. ${ }^{38}$ In rabbit bone marrow hyaluronic acid is only a minor component $(16 \%)$ of the proteoglycans in the extra-cellular matrix. ${ }^{39}$ An increase in the quantity of hyaluronic acid, because of its large molecular domain, may contribute to the inhibition of haemopoietic activity by restricting the diffusion of haemopoietic growth factors $^{22}$ or by preventing the adhesion of haemopoietic progenitor cells to stromal components. ${ }^{40}$

The accumulation of actively phagocytic macrophages was a further striking abnormality in many of the patients studied. Macrophages have emerged as a key element in current concepts about the pathogenesis of multiple organ failure, ${ }^{4142}$ and their presence in the bone marrow may have important implications for haemopoiesis. Macrophages produce a wide variety of secretory products, ${ }^{43}$ including the cytokines IL-1, IL-2, and TNF, together with reactive oxygen intermediates. TNF, in addition to its possible role in the 
pathogenesis of multiple organ failure, ${ }^{42}$ also inhibits haemopoietic progenitor cell growth in vitro $^{44} 45$ and may contribute to the anaemia of malaria by promoting dyserythropoiesis and erythrophagocytosis, ${ }^{46}$ both of which were features commonly observed in this study. Reactive oxygen intermediates also inhibit haemopoietic progenitor cell growth in vitro, both in short ${ }^{47}$ and long term ${ }^{48}$ bone marrow culture systems, and may therefore be a further factor implicated in the development of impaired haemopoiesis. Finally, it is of interest that oxygen radicals, released by stimulated human macrophages, have been shown directly to damage DNA in cultured mammalian cells. ${ }^{49}$ Furthermore, megaloblastic change is a feature of erythroid colonies grown in vitro in the presence of monocytes. ${ }^{50}$ It may be, therefore, that the megaloblastic change noted in some of our patients is also related to macrophage proliferation and DNA damage by released reactive oxygen intermediates.

We thank the medical and nursing staff of the intensive care unit at St Bartholomew's Hospital for their help and co-operation and the technical staff of the Department of Histopathology for their expert assistance.

1 Norwood SH, Civetta JM. Evaluating sepsis in critically ill patients. Chest 1987;92:137-44.

2 Lee GR. The anaemia of chronic disease. Semin Haematol 1983;20:61-80.

3 Samson D. The anaemia of chronic disorders. Postgrad Med $J$ 1983;59:543-50.

4 Lenz G, Goes U, Baron D, Sugg U, Heller W. Red blood cell $T$-activation and haemolysis in surgical intensive care patients with severe infection. Blut 1987;54:89-96.

5 Baue AE. Multiple, progressive, or sequential systems failure. Arch Surg 1975;110:779-81.

6 Border JR, Chenier R, McMenamy RM, et al. Multiple systems organ failure: muscle fuel deficit with visceral protein malnutrition. Surg Clin North Am 1976;56: 1147-67.

7 Eiseman B, Beart R, Norton L. Multiple organ failure. Surg Gynaecol Obstet 1977;144:323-6.

8 DeCamp MM, Demling RH. Post-traumatic multi system organ failure. JAMA 1988;260:530-4.

9 Filkins JP. Monokines and the metabolic pathophysiology of septic shock. Fed Proc 1985;44:300-4.

10 Clowes GHA, George BC, Villee CA, Saravis CA. Muscle proteolysis induced by a circulating peptide in patients

11 Galvani DW. Cytokines: biological function and clinical use. $J$ Roy Coll Phys (Lond) 1988;22:226-31.

12 Fibbe WE, Goselink HM, Van Eeden G, et al. Proliferation of myeloid progenitor cells in human long term bone marrow cultures is stimulated by interleukin-1 beta. Blood 1988;72:1242-7.

13 Beutler B, Cerami A. Cachectin: more than a tumour necrosis factor. $N$ Engl J Med 1987;316:379-85.

14 Clark SC, Kamen R. The human haemopoietic colonystimulating factors. Science 1987;236:1229-37.

15 Sieff CA, Niemeyer CM, Mentzer SJ, Faller DV. Interleukin-1, tumour necrosis factor, and the production of colony stimulating factors by cultured mesenchymal cells. Blood 1988;72:1316-23.

16 Fibbe WE, Van Damme J, Billian A, et al. Human fibroblasts produce granulocyte-CSF, macrophage-CSF and granulocyte-macrophage-CSF following stimulation by interleukin-1 and poly (rI), poly (rC). Blood 1988; 72:860-6.

17 Ridgway D, Borzy MS, Bagby GC. Granulocyte macrophage colony-stimulating activity produced by cultured human thymic non lymphoid cells is regulated by endogenous interleukin-1. Blood 1988;72:1230-6.

18 Mochizuki DY, Eisenman JR, Coulon PJ, Larsen AD, Tushinski RJ. Interleukin 1 regulates haemopoietic activity, a role previously ascribed to haemopoietin 1 . Proc Natil Acad Sci USA 1987;84:5267-71.

19 Metcalf $D$. Detection and analysis of human granulocytemonocyte precursors using semi-solid agar cultures. Clin monocyte precursors using

20 Burgess AW, Wilson EMA, Metcalf D. Stimulation by human placental conditioned medium of haemopoietic colony formation

21 Amos RJ, Amess JAL, Hinds CJ, Mollin DL. Incidence and pathogenesis of acute megaloblastic change in patients receiving intensive care. Lancet 1982;ii:835-9.

22 Iozzo RV. Proteoglycans: structure, function and role in neoplasia. Lab Invest 1985;53:373-96.

23 Michael P. Gelatinous degeneration of the bone marrow. $J$ Pathol 1930;33:533-8.

24 Seaman JP, Kjeldsberg CR, Linker A. Gelatinous transformation of the bone marrow. Hum Pathol 1978;9:685-92.

25 Cornbleet PJ, Moir RC, Wolf PL. A histochemical study of bone marrow hypoplasia in anorexia nervosa. Virchows bone marrow hypoplasia in anorexia

26 Mant MJ, Faragher BS. The haematology of anorexia nervosa. Br J Haematol 1972;23:737-49.

27 Tavassoli M, Eastlund DT, Yam LT, Neiman RS, Finkel H. Gelatinous transformation of bone marrow in prolonged self-induced starvation. Scand J Haematol 1976;16:311-9.

28 Amrein PC, Friedman R, Kosinski K, Ellman L. Haematologic changes in anorexia nervosa. JAMA 1979;241:2190-1.

29 Smith RL, Spivak JL. Marrow cell necrosis in anorexia nervosa and involuntary starvation. $\mathrm{Br} \mathrm{J}$ Haematol 1985;60:525-30.

30 Steinberg SE, Nasraway S, Peterson L. Reversal of serous atrophy of the bone marrow in anorexia nervosa. J Parent atrophy of the bone marr

31 Wagner S, Wood S, Amess JAL. Pancytopenia in a patient receiving home intravenous nutrition. Eur J Clin Nutri 1988;42:1029-34.

32 Keating A, Gordon MY. Hierarchical organisation of haemopoietic micro environments: role of proteoglycans. Leukaemia 1988;2:766-9.

33 Gordon MY. Extracellular matrix of the marrow microenvironment. Br J Haematol 1988;70:1-4.

34 McCuskey RS, Meineke HA, Townsend SF. Studies of the haemopoietic microenvironment. I. Changes in the microvascular system and stroma during erythropoietic regeneration and suppression in the spleens of CFI mice. Blood 1972;39:697-712.

35 Ploemacher RE, van't Hull E, van Soest PL. Studies of the haemopoietic microenvironments: effects of acid mucopolysaccharides and dextran sulphate on erythroid mucopolysaccharides and dextran sulphate on erythroid and granuloid

36 Gordon MY, Riley GP, Watt SM, Greaves MF. Compartmentalisation of a haemopoietic growth factor (GM-CSF) by glycosaminoglycans in the bone marrow microenvironment. Nature 1987;326:403-5.

37 Roberts R, Gallagher J, Spooncer E, Allen T $\bar{D}$, Bloomfield F, Dexter TM. Heparin sulphate bound growth factors; a mechanism for stromal mediated haemopoiesis. Nature 1988;332:376-8.

38 Del Rosso M, Cappelletti R, Dini G, et al. Involvement of glycosaminoglycans in detachment of early myeloid precursors from bone marrow stromal cells. Biochim Biophys Acta 1987;676:129-36.

39 Oguri K, Okayama E, Caterson B, Okayama M. Isolation, characterisation and localisation of glycosaminoglycans in rabbit bone marrow. Blood 1987;70:501-10.

40 Toole B. Glycosaminoglycans in morphogenesis. In: Hay ED, ed. Cell biology of the extracellular matrix. New York: Plenum Press, 1981:259-94.

41 Border JR. Sepsis, multiple systems organ failure and the macrophage. Arch Surg 1988;123:285-6.

42 Doran JE, Lundsgaard-Hansen P. Role of the reticuloendothelial system and the pathogenesis of organ damage. $B$ $J$ Hosp Med 1988;39:221-5.

43 Nathan CF. Secretory products of macrophages. J Clin Invest 1987;79:319-26.

44 Degliantoni G, Murphy M, Kobayashi M, Francis MK Perussia B, Trinchieri G. Natural killer (NK) cell derived haemopoietic colony inhibiting activity and NK cytotoxic factor: relationship with tumour necrosis factor and synergism with immune interferon. $J$ Exp Med 1985;162:1512-30.

45 Broxmeyer HE, Williams DE, Lu L, et al. The suppressive influences of tumour necrosis factors on bone marrow haemopoetic progenitor cells from normal donors and patients with leukaemia: synergism of tumour necrosis patients with leukaemia: synergism of tumour necrosis. factor and

46 Clark IA, Chandri G. Tumour necrosis factor may contribute to the anaemia of malaria by causing dyserythropoiesis and erythrophagocytosis. $\mathrm{Br} J$ Haemato 1988;70:99-103.

47 Ohkawa M, Shikano T, Ueno N. The effect of monocyte released oxygen metabolites on colony formation of eryth roid progenitor cells. Acta Haematol Japonica 1986; 49:1140-6.

48 Meagher RC, Salvado AJ, Wright DG. An analysis of the multi lineage production of human haemopoietic progenitors in long term bone marrow culture: evidence that reactive oxygen intermediates derived from mature phagocytic cells have a role in limiting progenitor cell self renewal. Blood 1988;72:273-81.

49 Weitberg AB, Weitzman SA, Destremps M, Latt SA, Stossel TP. Stimulated human phagocytes produce cytogenetic changes in cultured mammalian cells. $N$ Engl $J$ Med 1983;308:26-30.

50 Reid CDL, Baptista LC, Deacon R, Chanarin I. Megaloblastic change is a feature of colonies derived from an early erythroid progenitor (BFU-E) stimulated by monocytes in culture. Br J Haematol 1981;49:551-61. 